\title{
Oceanographic Research of Marine Hydrophysical Institute in the Southern Ocean
}

\author{
Yu.V. Artamonov, E.A. Skripaleva \\ Marine Hydrophysical Institute, Russian Academy of Sciences, Sevastopol, Russian Federation \\ e-mail: artam-ant@yandex.ru
}

\begin{abstract}
Basic stages of the oceanographic research carried out by Marine Hydrophysical Institute in the Southern ocean are considered. Each stage of the studies is illustrated by the schemes of expeditionary work; the most important results are presented. The oceanographic studies of Marine Hydrophysical Institute in the Southern ocean are shown to be developed in two basic directions: marine expeditionary research and analysis of the archival hydrometeorological data. Based on the results of expeditionary studies, the mechanisms of formation and variability of the water structure and circulation in the Antarctic coastal regions are described. Anomalies of hydrometeorological fields occurring along the route to Antarctica are assessed due to the measurements from the passing vessels. The archival hydrological and satellite data constitute a foundation for revealing the features of seasonal and interannual variability of the ocean surface temperature, fronts and sea ice in Antarctica. The effect of El Niño events on the interannual variation of the characteristics of Scotia Sea Front is revealed. It is shown that the formation of warm water positive anomaly areas in the tropical Pacific is caused by El Niño events. It's accompanied by an appreciable displacement of the front to the south, by the weakening of its intensity and the decrease of temperature on the front axes. It is shown that maximum seasonal variation of the ice concentration is observed in the Weddell and Lazarev Seas. The ice in the Weddell, Amundsen and Bellingshausen Sea are shown to be exposed to the highest interannual variability.
\end{abstract}

Keywords: the Southern ocean, Antarctic expeditions, passing hydrometeorological measurements, thermohaline fields, fronts, temperature trends, the Antarctic Circumpolar current.

DOI: 10.22449/1573-160X-2016-6-56-66

(C) 2016, Yu.V. Artamonov, E.A. Skripaleva

(C) 2016, Physical Oceanography

The history of oceanographic research of Marine Hydrophysical Institute (MHI) in the Southern Ocean begins in the 70s of the last century, when MHI scientific research vessels carried out research in various areas of the World Ocean, including the polar and subpolar latitudes of the Southern Hemisphere. Hydrological measurements in these areas were performed in the $20^{\text {th }}$ and $30^{\text {th }}$ cruises R/V Mikhail Lomonosov and in the 4, 5, 10 and $24^{\text {th }}$ cruises of R/V Akademik Vernadsky (Fig. 1). During this period, the MHI research in the Southern Ocean have not been goal seeking. It was carried out within the World Ocean Tropical and Moderate Latitude Research Program framework. At that time the hydrological works were extremely seldom carried out in the Southern Ocean. Consequently, even the relatively small amount of information, obtained by MHI undoubtedly contributed to the study of this area. For example, in the $10^{\text {th }}$ cruise of R/V Akademik Vernadsky (January, 1975) the oceanographic research on the Antarctic Circumpolar Current (ACC) structure along $20^{\circ} \mathrm{E}$ were carried out for the first time. In addition to the complex hydrological and hydrochemical measurements the autonomous buoy stations with current meters were applied. The meridional ACC structure was first to be described based on the data of instrumental measurements. It was also shown to consist of several branches. The most intensive branches were located in the $39^{\circ}$ 
and $48^{\circ} \mathrm{S}$ and coincided with the position of the Subantarctic (SAF) and the Antarctic Polar (APF) fronts. Zonal velocities in these branches were 80 and $40 \mathrm{~cm} / \mathrm{s}$ respectively. It has been found that the absolute maximum of the ACC velocity (up to $100 \mathrm{~cm} / \mathrm{s}$ ) is observed at depths of $100-200 \mathrm{~m}$ and not in the ocean surface, as it was previously considered. Instrumental measurements of currents gave reason to believe that there is the deep-water countercurrent under the ACC [1].

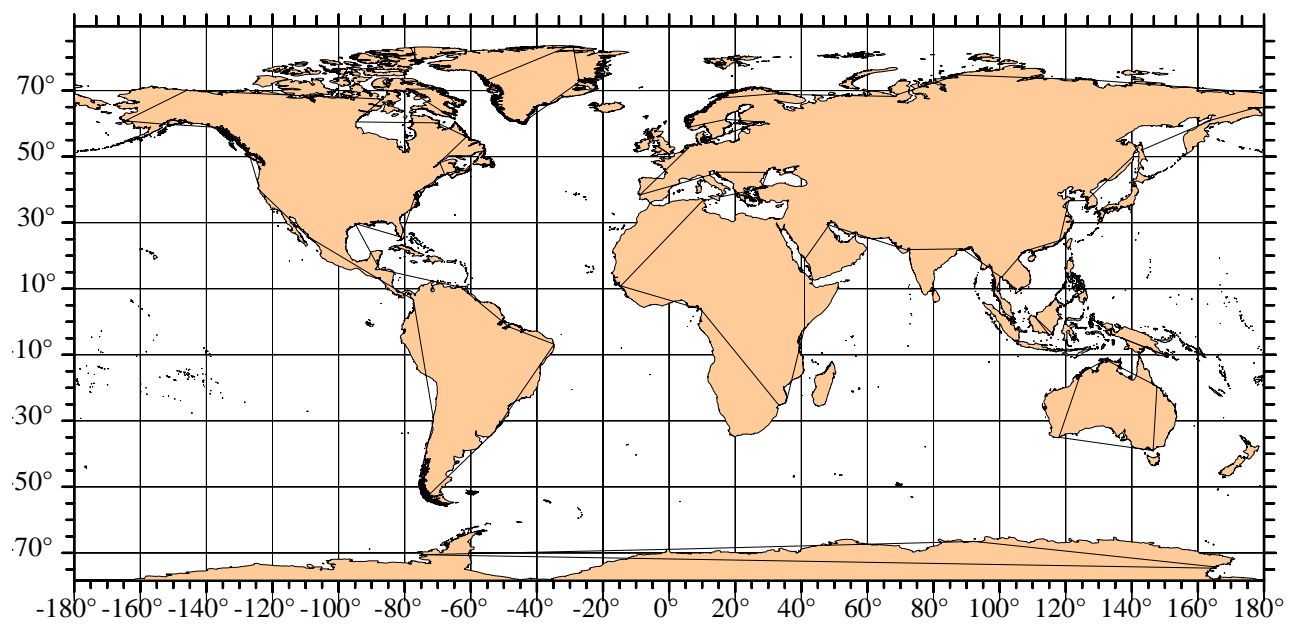

Fig. 1. Oceanographic research areas of R/V Mikhail Lomonosov and Akademik Vernadsky (MHI AS USSR) in the Southern Ocean

The large amount of oceanographic information in the subantarctic zone of the Southern Ocean was obtained in R/V Mikhail Lomonosov $30^{\text {th }}$ cruise, which was carried out within the framework of Southern Gyre project in winter 1976. The SAF structure in the south-eastern part of the Atlantics was firstly described. It was found that in the front zone at the convergence of Brazilian and Falkland Current geostrophic velocities can reach $150-250 \mathrm{~cm} / \mathrm{s}$. Also, the meandering nature of the SAF and the formation of synoptic eddies on its periphery were discovered [2]. MHI started its systematic studies in Antarctica after the transfer to Ukraine the British Antarctic base Faraday, subsequently - Akademik Vernadsky Research Base. In 1997, the MHI scientists took part in the first (after the Soviet period) complex oceanographic expedition on R/V Ernst Krenkel. A large-scale survey in the South Orkney and South Shetland Islands and hydrological stations in the waters of the Argentine Islands Archipelago were carried out (Fig. 2). Research on R/V Ernst Krenkel was continued in 1998. In 2000 and 2002 there were two expeditions on $\mathrm{R} / \mathrm{V}$ Horizont, which included oceanographic research in the western Bransfield Strait, in the lagoon of the Deception Island near the Akademik Vernadsky Research Base.

The regular expeditions to Antarctica in 1997 - 2002 resulted in the accumulation of a significant amount of data on thermohaline and kinematic water structure of the Antarctica Atlantic sector. About two dozens of the serial hydrological stations were made in the Archipelago of the Argentine Islands to the west of the Antarctic Peninsula. The unique data on the mesoscale structure and 
water circulation in shallow waters of the Antarctic Peninsula western shelf $[3,4]$ was obtained. It was found that the diurnal and interdiurnal variability $T, S$-structure of water on the shelf is due to daily variations of meteorological parameters and the water advection by the drift currents, varying depending on the prevailing wind. This complex pattern is superimposed by periodic water advection by tidal currents, which can be characterized by both diurnal and semidiurnal periods.

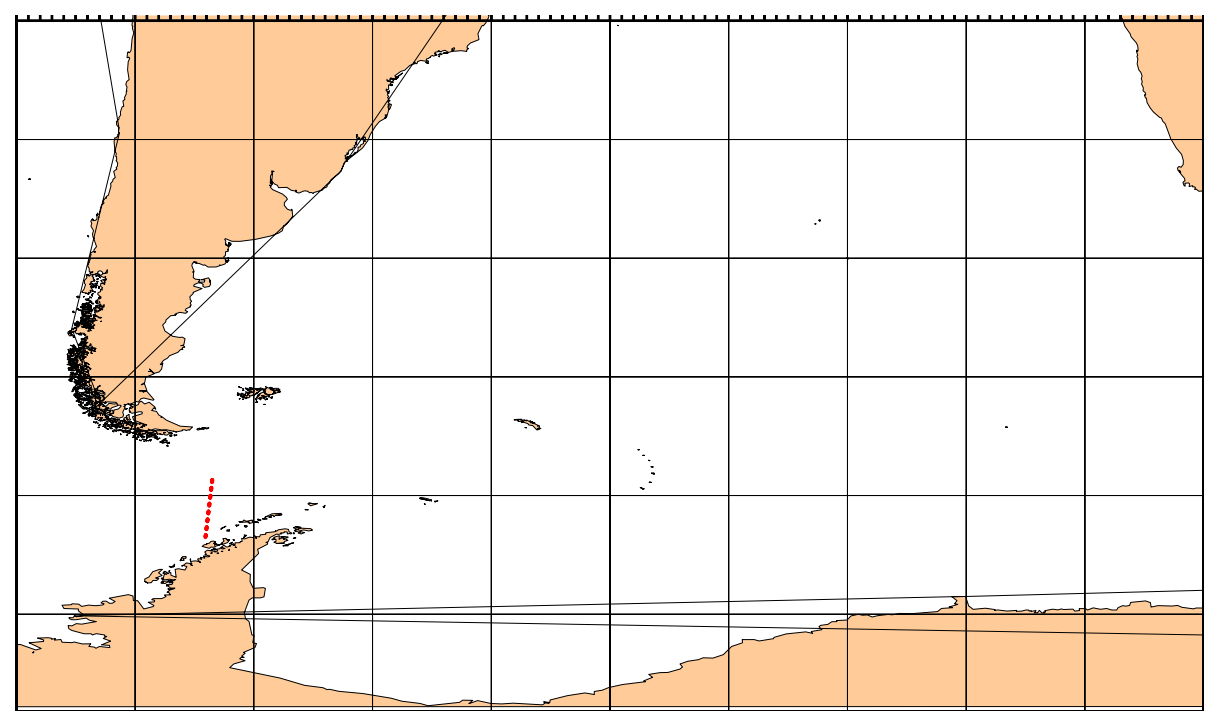

Fig. 2. Oceanographic research areas of R/V Ernst Krenkel and Horizont (MHI NAS of Ukraine) in the Southern Ocean

Based on passing hydrometeorological measurements of the vessel, it was possible to draw some conclusions about the peculiarities of interannual variations in the hydrological structure of water. It has been shown that in February - April 1998, in the Southern Polar and Antarctic climatic zones negative temperature and salinity anomalies were observed. They were accompanied by a displacement of the largescale fronts to the north (SAF and APF), intensification of currents and the transport of the anomalously large number of icebergs out of the Weddell Sea [5].

The results obtained within the framework of the Ukrainian Antarctic Research Program made it possible to outline a strategy for further expeditionary works [6]. Unfortunately, due to financial obstacles the Ukrainian marine research has been ceased since 2003. The hydrological works were limited to coastal measurements in the area of the Akademik Vernadsky Research Base [6].

The marine research activities in Antarctica was stepped up in 2007 - 2008, when Ukraine became involved in oceanographic research conducted on R/V Akademik Fedorov in the framework of the International Polar Year $\left(53^{\text {rd }}\right.$ Russian Antarctic Expedition - 53 RAE) [4]. These studies were continued in 2009 - 2010 (55 RAE) within the joint Russian-Ukrainian program Research of modern climate changes in the South Polar Region and their manifestations in the region of the Antarctic Peninsula and in 2011 - 2012 (57 RAE) - in the framework of the project Variability 
of the ocean and atmosphere interaction parameters and oceanographic characteristics of the Southern Ocean, including coastal areas of Antarctica.

Having become a member of the Russian Academy of Sciences, Marine Hydrophysical Institute continued the expeditionary works in Antarctica in $61^{\text {st }}$ RAE under the MHI scientific theme "Fundamental research of hydrophysical, hydrochemical, hydrooptical field variability and the atmosphere and ocean interaction within a wide range of spatial and temporal scales" and Russian State program "Environmental Protection".

The MHI scientists together with our Russian colleagues have carried out 25 longitudinal hydrological measurements (stations) near Antarctica for the period 2007 - 2016 (Fig. 3). It has been shown that factors influencing on the variability of water structure identified in Archipelago of the Argentine Islands, are universal and active around the whole of Antarctica, but in some areas the waters possess regional characteristics.

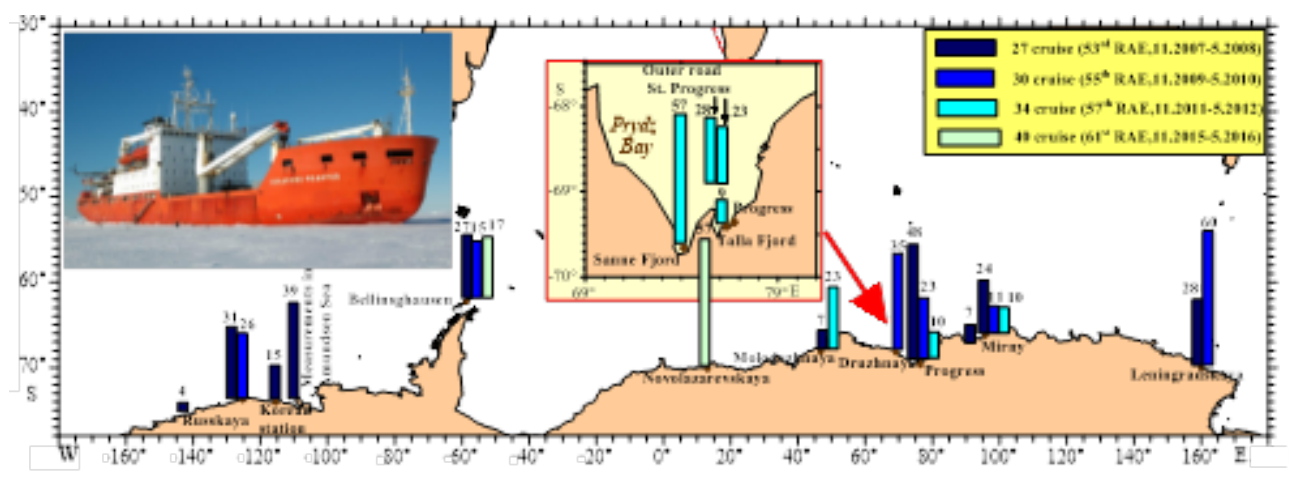

Fig. 3. Position of the serial oceanographic stations carried out buy the MHI scientists from the board of $\mathrm{R} / \mathrm{V}$ Akademik Fedorov off Antarctica coast. The number of probes is marked by digits

Although the MHI specialists have gathered quite a large amount of factual material on the mesoscale and synoptic water variability in the coastal areas of Antarctica, the number of serial stations is still insufficient to make reliable scientific conclusions. For example, the vertical variability in hydrological structure of Sanne Fjord Gulf in January 2012 was characterized by the appearance of layers of anomalously warm water with a maximum temperature of $-0.2 \ldots$ $0.3^{\circ} \mathrm{C}$ and the core depth of $40-60 \mathrm{~m}$ (Fig. 4, a). The warming of the subsurface layer was accompanied by its freshening (Fig. 4, b) [7]. A year before (January, 2011) the longitudinal hydrological station was carried out in the same place. A layer of warm subsurface waters was also observed in the temperature distribution. At that, the core of the warm waters in January, 2011 was located closer to the surface at a depth of $12-18$ meters. The highest maximum temperature in the core reached $1.6-1.7^{\circ} \mathrm{C}$. The observed differences in the temperature distribution between the two one-year interval executed stations is difficult to explain, since the mechanism of the formation of warm water layers is still vague. Probably, their source can be the waters, which were formed on the eastern shelf of Prydz Bay in the summer and came with the alongshore current to Sanne Fjord Gulf [7]. 

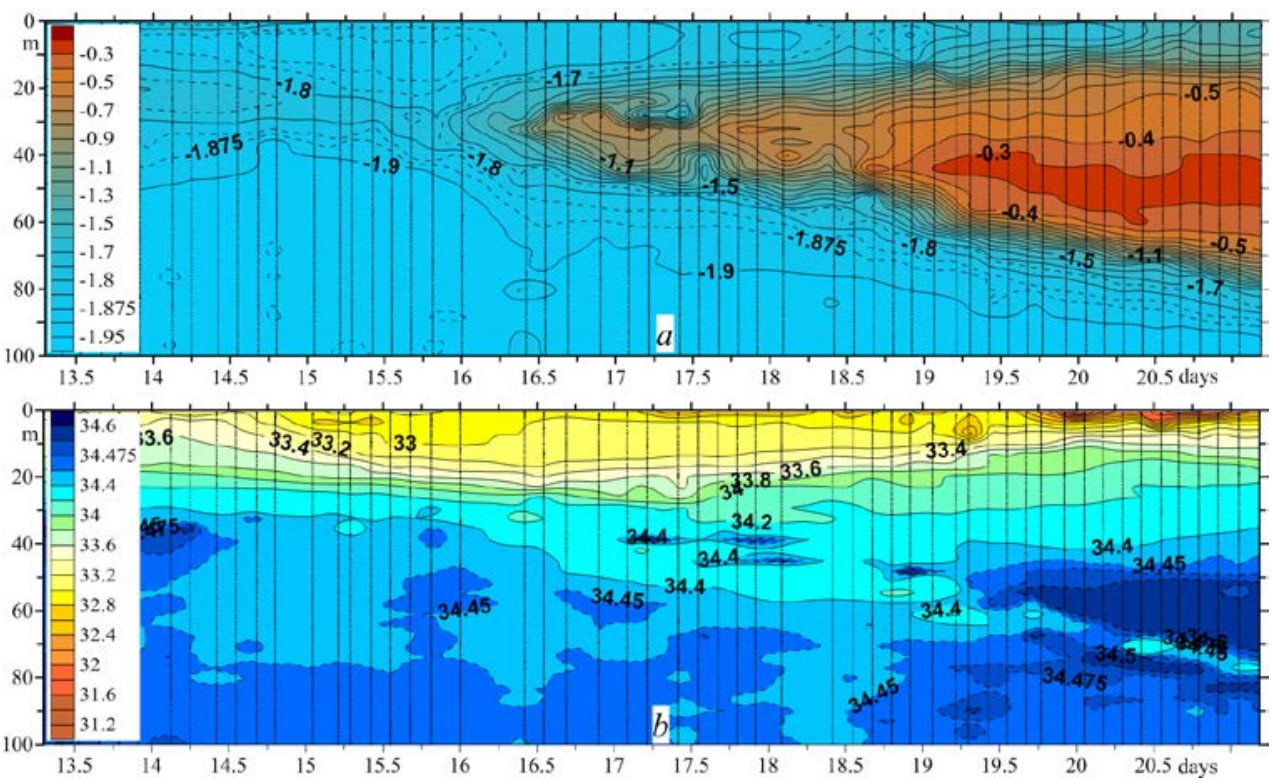

Fig. 4. Time variation of temperature $(a)$ and salinity $(b)$ within the period of the multidiurnal hydrological measurements in Sanne Fjord Gulf $(13$ - 21.01.2012)

Another direction of the research carried out by the MHI specialists in the Antarctic expeditions was the analysis of the passing meteorological measurements fulfilled on the route of vessels to Antarctica and back (Fig. 5). Continuous measurements in passing of the vessel show the condition of meteorological fields in large water areas within a relatively short time period allowing estimating the degree of their anomaly.

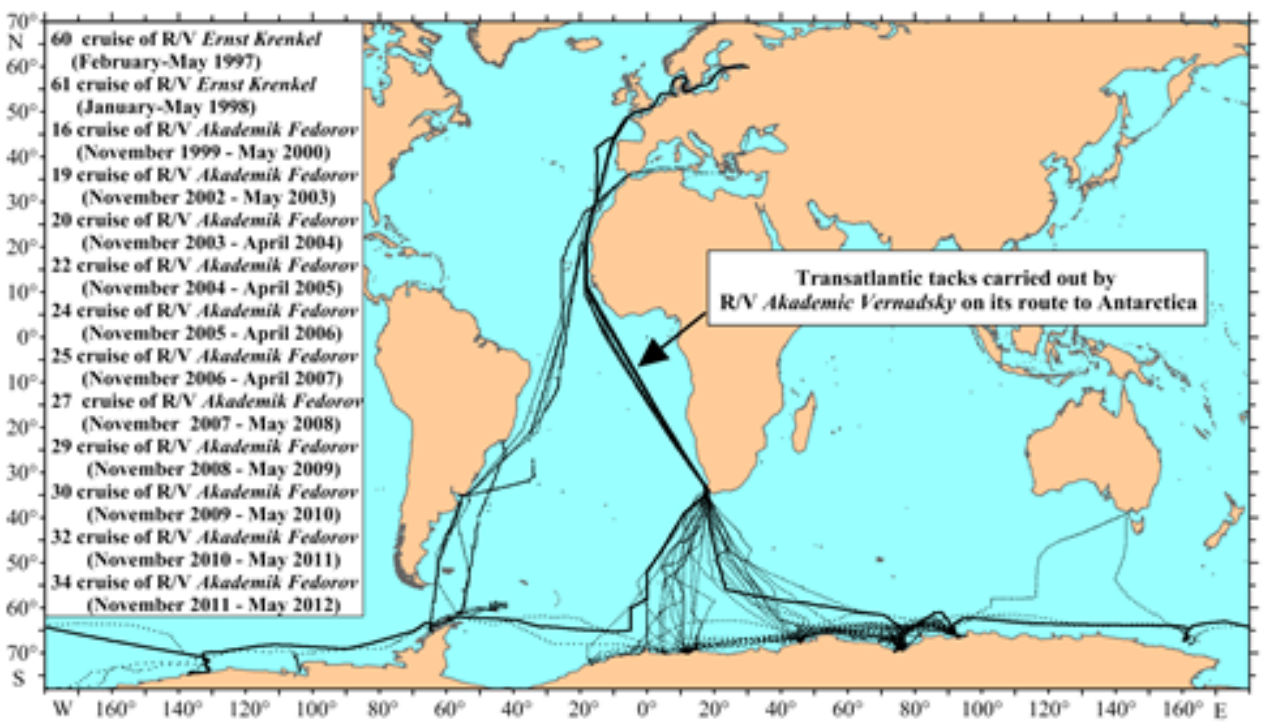

Fig. 5. Routes of the vessels in the Antarctic expeditions within the period of $1997-2012$ 
As an example, the data processing results of the passing measurements on R/V Akademik Fedorov are demonstrated below. These measurements were carried out on the regular transatlantic tacks in all the cruises in the 1999-2011 practically in the same route and in the same season (November) [8]. Distribution of sea surface temperature (SST), obtained by the contact method during the cruises, were compared with the climatic distributions of SST taken from the reanalysis array of the National Center for Environmental Prediction (NCEP).

Fig. 6 shows that positive anomalies, reaching $2-2.5^{\circ} \mathrm{C}$, are most frequently observed off $25^{\circ} \mathrm{N}$, where the SST distribution is affected by coastal upwelling. Another area, the positive anomalies are often monitored in, is the latitudinal band between $10^{\circ} \mathrm{N}$ and $5{ }^{\circ} \mathrm{S}$. Third maximum of positive values of SST anomalies is observed in the port of Cape Town in the South Africa upwelling area. Since 2004, there is a general tendency to increase the area of positive anomalies. The exception is the transatlantic tacks made in November 2008, when a strong negative SST anomaly was observed in the Northern Hemisphere, and in November 2011, when the negative SST anomaly appeared between $15^{\circ}$ and $25^{\circ} \mathrm{S}$ [8].

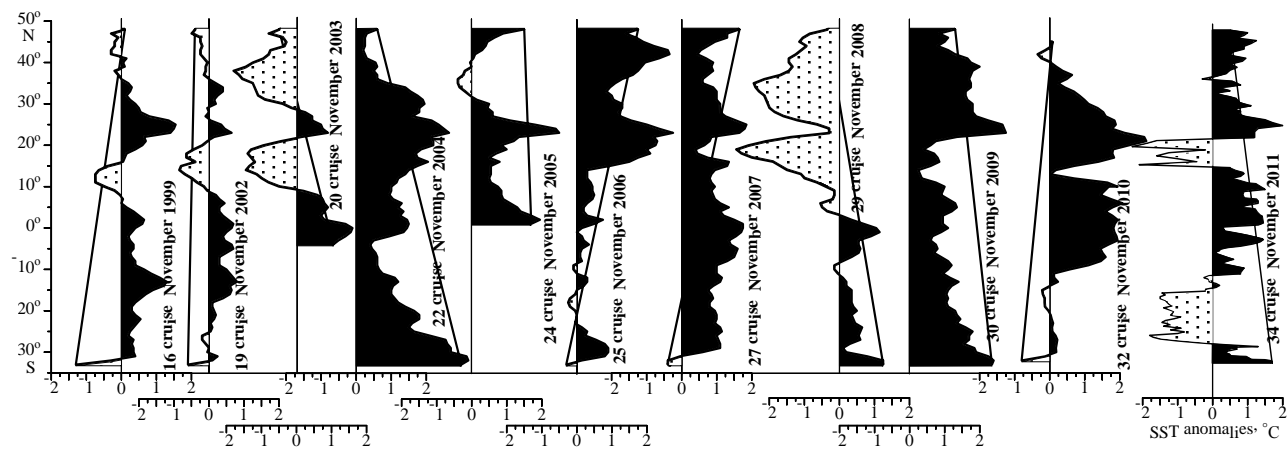

Fig. 6. Distribution of SST anomalies, calculated as the difference between the actual measured SST and the average climate one for November according to the NCEP array data, along R/V Akademik Fedorov transatlantic tacks

Time series of measurements on a transatlantic tack is still relatively short, to make quantitative estimates of variability of SST anomalies on the tack with the variability of atmospheric circulation indices. Qualitatively, it can be stated that the relatively weak negative SST anomalies in 1999 - 2002 coincided with the positive phase of the Southern (SO) and Antarctic (AAO) oscillations. In 2003 - 2007, when the values of the $\mathrm{SO}$ and $\mathrm{AAO}$ indices were predominantly negative, positive SST anomalies were observed. Negative SST anomalies in the Northern Hemisphere at the end of 2008 accounted for the period of intensive growth of the positive values of the SO index and the minimum ones of AAO index. Negative anomaly in the south of tack in 2011 was monitored during the positive phase of the $\mathrm{SO}$ and AAO.

In addition to the expeditionary measurements in Antarctica, the MHI scientists carried out the research based on modern archive database. According the British Atmospheric Data Centre HadISST (BADC), the positive trends of SST PHYSICAL OCEANOGRAPHY NO. 6 (2016) 
(Fig. 7) have been prevailing in the Southern Ocean for the last half of the century, which is consistent with modern concepts of global warming of the World Ocean [9]. High positive SST trends $\left(\sim 1-2.5^{\circ} \mathrm{C}\right)$ were observed in the areas of the following boundary currents: the Peru Current, the Brazilian and Falkland Current Convergence Zone, the Benguela and Mozambique Current, the West and the East Australian Current. Positive trends in the western boundary currents, following to the south, show an increase in the interannual scale of the transport of warm tropical waters in temperate latitudes, and v.v., in the eastern boundary currents, following to the north, the transport of cold water in the tropical latitudes is reduced.

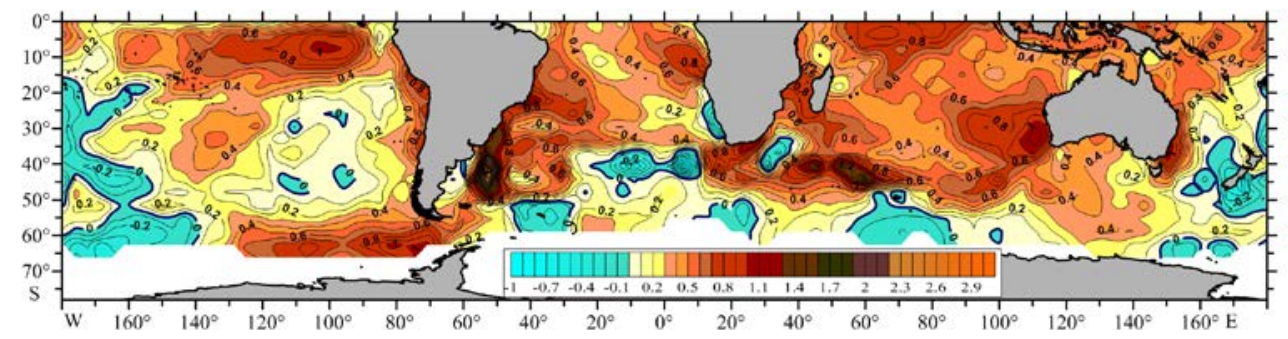

Fig. 7. Distribution of the SST linear trends calculated within the period of $1950-2002$ according to the BADC data

New data on the reaction of SST in the Southern Hemisphere to the El Niño event is obtained [10]. It is shown that there is a change of a sign of crosscorrelation function $R(\tau)$ between the time series of interannual SST anomalies and SO index values from the negative $(-0.8)$ at the equator to the positive $(0.65)$ closer to the Southern Subtropical Anticyclonic Gyre (SSAG) (Fig. 8, a). Time lag of the SST response to the SO effect is $2-6$ months (Figure $8, b$ ). To the south of SSAG values of $R(\tau)$ vary from 0.6 in the zone of the South Pacific Current to -0.6 in the ACC zone.

The positive relationship between SST anomalies and values of SO index to the south of the tropical zone and in the western boundary layer confirms the fact that the strengthening (weakening) of trade-wind circulation leads to the strengthening (weakening) of the transport of warm equatorial waters to the subtropical and temperate latitudes and contributes to positive (negative) anomalies of SST. The feedback between SST anomalies in the ACC zone and variability of SO index can be explained by the fact that during the trade-wind circulation increasing (weakening) the same process is monitored with the AAO in the Pacific sector. So, as a consequence, there is an increase (weakening) of the meridional transport of the cold waters from the Antarctic area to the north and the formation of negative (positive) anomalies of SST.

The specialists of Marine Hydrophysical Institute carried out a series of studies on seasonal and interannual variability of the Southern Hemisphere water structure and fronts on the basis of satellite data [11 - 14]. For example, the research of variability the Scotia Sea Front (SSF). This sea is of great fishing and trade importance. The aforementioned studies showed that in the climatic seasonal cycle the SSF intensifies during the warmer months, when there is a strengthening of the 
temperature contrasts between the cold waters, formed by the ice melting, and the warmer waters of the ACC. The maximum intensity of the SSF seasonal fluctuations were observed in the area of minimum of the displacements of ice boundary intra-annual oscillations [13].

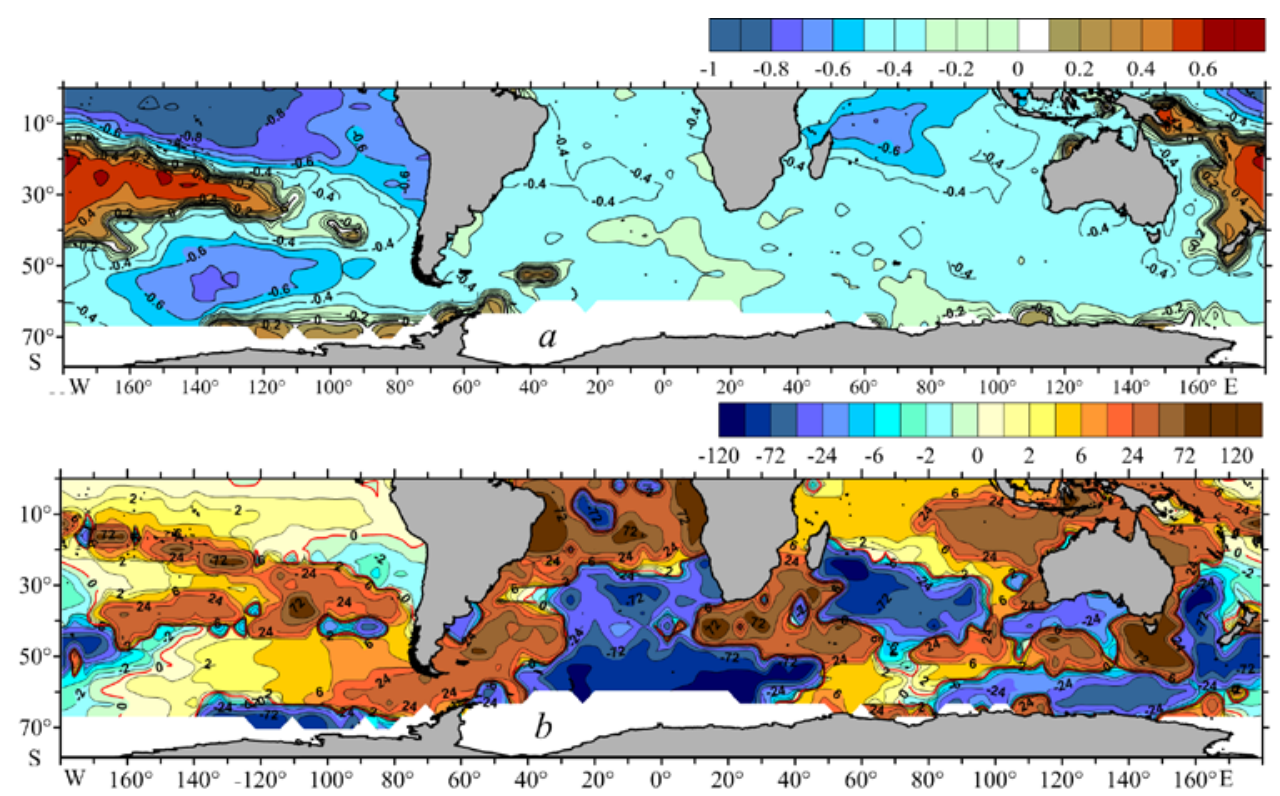

Fig. 8. Spatial distribution of the extreme values of cross-correlation functions $R(\tau)(a)$ and time lag $\tau$ (month) $(b)$ between the SST anomalies and SO index

The effect of El Niño events on the interannual variation of the characteristics of polar fronts is revealed. It is shown that the formation of warm water positive anomaly areas in the tropical Pacific is caused by El Niño events. It's accompanied by a appreciable displacement of the SSF to the south, by the decrease of temperature on the front axes and the weakening of its intensity with the significant coefficients of correlation $\sim 0.6$ in absolute value. It is noted that the relationship between the SSF characteristics and El Niño is due to the peculiarities of propagation of thermal anomalies. These anomalies move southward to moderate and polar latitudes from the tropical Pacific. Then they get into the ACC, having effect on the SSF characteristics. As the anomalies propagate eastward, this effect is weakening.

New results were obtained in the study of seasonal and interannual variations of the ice concentration in Antarctica [15]. Its maximum seasonal variation is observed in the Weddell and Lazarev Seas, where the greatest seasonal displacements of sea ice border are monitored. The minimum seasonal variability of ice concentration is found in the coastal areas of Antarctica, where the ice shelves are situated.

The ice in the Weddell, Amundsen and Bellingshausen Sea are shown to be exposed to the highest interannual variability. The interannual mean squared (RMS) deviation $\left(\mathrm{RMS}_{\text {int }}\right.$ ) values are almost an order of magnitude greater than in other regions. The zone of intense interannual variation of ice concentration is

PHYSICAL OCEANOGRAPHY NO. 6 (2016) 
located southward of the main ACC jet, which is the natural border of their

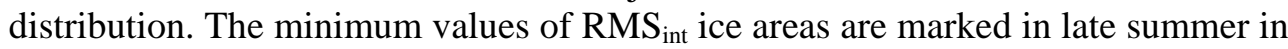
the period of the minimum amount of ice around the continent. In March - April the growth of $\mathrm{RMS}_{\text {int }}$ values starts and reaches its peak in June for ice concentration of $100 \%$. For $80-90 \%$ ice concentration the growth of $\mathrm{RMS}_{\text {int }}$ value continues until September. Generally, the period of greatest $\mathrm{RMS}_{\text {int }}$ values roughly coincides with the period of the greatest amount of ice around Antarctica.

It was found that El Niño events are reflected in the behavior of monthly anomalies of the total sea ice areas of $90-100 \%$ concentration. It is manifested in the changes of the amplitude of seasonal fluctuations, the duration of ice formation and melting seasons and in the ratio of positive and negative anomalies in the seasonal cycle.

The spatial structure of correlation relations between sea ice concentration and $\mathrm{SO}$ and AAO indices is characterized by elongated regions with extreme values of correlation coefficients $\left(\mathrm{R}_{\mathrm{SO}}, \mathrm{R}_{\mathrm{AAO}}\right)$ in the meridional direction, due to the prevailing direction of ice drift on the peripheries of large-scale cyclonic circulations formed off the coast of Antarctica.

Maximum direct correlative relation between ice concentration and variations of SO index values $\left(\mathrm{R}_{\mathrm{SO}} \sim 0.6\right)$ is marked in most of the interannual variability of ice concentration $\left(130-150^{\circ} \mathrm{W}, 60-65^{\circ} \mathrm{S}\right)$. In this case the ice concentration reaction to the SO index changes occurs practically without delay. Positive correlation areas $\left(\mathrm{R}_{\mathrm{SO}} \sim 0.3-0.5\right)$ are also observed to the west of the Antarctic Peninsula and in the Cooperation Sea, while the response of sea ice on the SO index change is delayed for $2-4$ years.

Significant correlative relations between the ice concentration and AAO index $\left(\mathrm{R}_{\mathrm{AAO}} \sim 0.2-0.4\right)$ are found in the Weddell Sea under the 2 year lag and in the area of $130-150^{\circ} \mathrm{W}, 60-65^{\circ} \mathrm{S}$ - under 1 year.

Conclusions. During the years of the MHI research in the Southern Ocean the scientific information base has been created. It expands the physical basis for the solution of the aforementioned problem. According to the results of expeditionary studies regularities of the formation and variability of water structure and circulation in the Antarctica coastal areas are described. As a result of passing vessel measurements the surface temperature anomalies along the route of vessels in Antarctica were estimated. On the basis of archival hydrological arrays and satellite data the seasonal cycle regularities and interannual variability features of SST field, fronts and sea ice of different concentrations were revealed. However, the factual material accumulated in MHI requires further analysis and interpretation in accordance with the constantly improving climate databases and the level of knowledge about the spatial and temporal variability of the World Ocean structure.

In the future, it is necessary to expand the experimental research of MHI in the areas of polar stations and to conduct regular oceanographic measurements, as the base of time implementations of hydrometeoparameter measurements in Antarctica is still limited by standard meteorology at polar stations. In addition to standard meteorological measurements it is necessary to establish hydrooptical and fine structure measurements, applying the instruments created in MHI. Expansion of the 
oceanographic research in the Southern Ocean is possible with the use of drift technologies, widely used by MHO in the Arctic.

Acknowledgements. The research was carried out within the framework of State Order No. 0827-2015-0001 "Fundamental research of the processes in the ocean - atmosphere - lithosphere system determining spatial-temporal variability of the global and regional scale environment and climate".

\section{REFERENCES}

1. Ganson, P.P., Krivosheya, V.G., Neyman, V.G. \& Tarasenko, V.M., 1977, “Eksperimental'nye issledovaniya Antarkticheskogo tsirkumpolyarnogo techeniya [Experimental studies of the Antarctic Circumpolar Current]”, Kompleksnye issledovaniya MGI AN USSR v Indiyskom okeane, pp. 99-105 (in Russian).

2. Latun, V.S., Artamonov, Yu.V. \& Belyakova, O.M., 1979, "Geostroficheskie techeniya v zone Yuzhnogo subtropicheskogo fronta [Geostrophic currents in the Southern Subtropical Front zone]”, Biologiya morya, Kiev, Naukova dumka, iss. 49, pp. 9-14 (in Russian).

3. Artamonov, Yu.V., Bulgakov, M.P., Vashchenko, V.M. \& Lomakin, P.D., 2006, "Okeanografichni doslidzhennya Ukrä̈ni v Atlantichnomu sektori Antarktiki (1997-2004) [Ukraine Oceanographic research in the Atlantic sector of Antarctica]”, Kyiv, Naukova dumka, 164 p. (in Ukrainian).

4. Artamonov, Yu.V., 2010, “Okeanograficheskie issledovaniya v ramkakh II-go ehtapa Gosudarstvennoy programmy issledovaniy Ukrainy v Antarktike [Oceanographic research in the framework of the 2nd stage of the State Program of Ukrainian research in Antarctica]", Ukrainskiy Antarkticheskiy zhurnal, no. 9, pp. 119 - 133 (in Russian).

5. Bulgakov, N.P., Artamonov, Yu.V. \& Bibik, V.A. [et al.], 2001, "Anomal'nye yavleniya v Atlantike $v$ fevrale - mae $1998 \mathrm{~g}$. [Anomalous phenomena in the Atlantic in February-May 1998]”, Okeanologiya, vol. 41, no 2, pp. 201-206 (in Russian).

6. Artamonov, Yu.V., 2013, "Gidrologicheskie issledovaniya na akvatorii arkhipelaga Argentinskie ostrova: problemy i perspektivy [Hydrological studies of the archipelago of the Argentine Islands: problems and prospects]”, Ukrainskiy Antarkticheskiy zhurnal, no. 12, pp. 113-125 (in Russian).

7. Artamonov, A.Yu., Artamonov, Yu.V. \& Bochkarev, V.I. [et al.], 2013, “Rezul'taty okeanograficheskikh issledovaniy $v$ pribrezhnykh rayonakh Indookeanskogo sektora Antarktiki v dekabre 2011 i yanvare - fevrale 2012 gg. (po materialam 57-y rossiyskoy antarkticheskoy ehkspeditsii) [The results of oceanographic research in coastal areas of the Indian Ocean sector of the Antarctica in December 2011 and January-February 2012 (based on RAE 57 proceedings)]”, Ukrainskiy Antarkticheskiy zhurnal, pp. 126-137 (in Russian).

8. Artamonov, Yu.V., Antipov, N.N. \& Bunyakin, V.P. [et al.], 2011, "Struktura i izmenchivost' polya temperatury poverkhnosti okeana na transatlanticheskikh galsakh po dannym poputnykh izmereniy na NES «Akademik Fedorov»v 1999-2010 gg. [The structure and variability of the sea surface temperature field in the transatlantic tacks according to free measurements on R/V Akademik Fedorov in 1999-2010]", Sistemy kontrolya okruzhayushchey sredy, Sevastopol, ECOSI-Gidrofizika, iss. 16, pp. 162-171 (in Russian).

9. Artamonov, Yu.V., Babiy, M.V., Bukatov, A.E. \& Skripaleva, E.A., 2008, "Regional'nye osobennosti sezonnoy izmenchivosti lineynykh trendov polya temperatury $v$ Atlanticheskom okeane i ikh svyaz's krupnomasshtabnoy tsirkulyatsiey vod [Regional features of the seasonal variation of the temperature field of linear trends in the Atlantic Ocean and their relation to the large-scale circulation of water]”, Morskoy gidrofizicheskiy zhurnal, no. 4, pp. 17-27 (in Russian).

10. Artamonov, Yu.V., Babiy, M.V., Bukatov, A.E. \& Skripaleva, E.A., 2009, “Korrelyatsionnye svyazi anomaliy temperatury poverkhnosti Tikhogo okeana i indeksa Yuzhnogo Kolebaniya [Correlation between surface temperature anomalies in the Pacific Ocean and the Southern Oscillation index]”, Ukrainskiy Antarkticheskiy zhurnal, no. 12, pp. 137-146 (in Russian).

PHYSICAL OCEANOGRAPHY NO. 6 (2016) 
11. Artamonov, Yu.V., Skripaleva, E.A., 2005, "Struktura i sezonnaya izmenchivost' krupnomasshtabnykh frontov Atlanticheskogo okeana po sputnikovym dannym [The structure and seasonal variability of the Atlantic Ocean large-scale fronts from satellite data]", Issledovanie Zemli iz kosmosa, no. 4, pp. 62-75 (in Russian).

12. Artamonov, Yu.V., Skripaleva, E.A., 2006, "Izmenchivost' gidrologicheskikh frontov Peruansko-Chiliyskogo sektora po sputnikovym dannym [Variability of hydrological fronts Peruvian-Chilean sector of satellite data]”, Ukrainskiy Antarkticheskiy zhurnal, no. 4-5, pp. 109-116 (in Russian).

13. Artamonov, Yu.V., Lomakin, P.D. \& Skripaleva, E.A., 2008, “Sezonnaya i mezhgodovaya izmenchivost' kharakteristik Fronta morya Skotiya po sputnikovym izmereniyam temperatury poverkhnosti okeana [Seasonal and interannual variability of the Scotia Sea Front features on satellite measurements of sea surface temperature]”, Morskoy gidrofizicheskiy zhurnal, no. 1, pp. 57-67 (in Russian).

14. Artamonov, Yu.V., Skripaleva, E.A., 2008, "Sezonnaya izmenchivost' krupnomasshtabnykh frontov vostochnoy chasti Tikhogo okeana po sputnikovym dannym [Seasonal variability of large-scale fronts of the eastern Pacific Ocean from satellite data]", Issledovanie Zemli iz kosmosa, no. 4, pp. 45-61 (in Russian).

15. Eremeev, V.N., Artamonov, Yu.V., Bukatov, A.A. \& Skripaleva, E.A., 2009, "Prostranstvennovremennaya izmenchivost' splochennosti morskogo l'da Antarktiki [Spatial and temporal variability of sea ice in Antarctica]”, Geoinformatika, no. 2, pp. 48-55 (in Russian). 